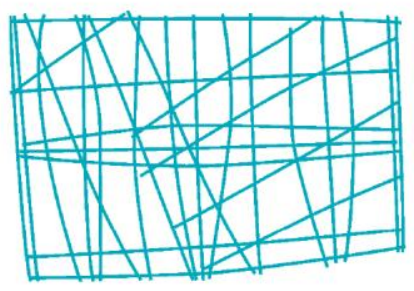

NEREUS

Núcleo de Economia Regional e Urbana

da Universidade de São Paulo

The University of São Paulo

Regional and Urban Economics Lab

ECONOMIC IMPACTS OF NATURAL DISASTERS IN MEGACITIES: THE CASE OF FLOODS IN SÃO PAULO, BRAZIL

Eduardo A. Haddad

Eliane Teixeira

TD Nereus 04-2013

São Paulo

2013 


\title{
Economic Impacts of Natural Disasters in Megacities: The Case of Floods in São Paulo, Brazil ${ }^{1}$
}

\author{
Eduardo A. Haddad and Eliane Teixeira
}

\begin{abstract}
The city of São Paulo, home to 11 million people, suffers constantly the effects of flooding caused by extreme precipitation. Localized floods occur every summer in various parts of the city. Besides the losses and inconvenience felt by the residents, floods produce damages that cross the city boundaries, affecting income and output in the metropolitan area as well as in other parts of the state and the country. The objective of this study is to evaluate the economic impacts of floods in the city of São Paulo through the use of a spatial CGE model integrated to GIS information related to the location of points of floods and the firms within their influence. It is estimated that floods contributed to reduce city growth and residents welfare, as well as to hamper local competitiveness in both domestic and international markets. An intra-city total impact-damage ratio of 2.2 and an economy-wide total impact-damage ratio of 5.0 were found.
\end{abstract}

\section{Introduction}

The relationship between urbanization of large agglomerations and flooding has been receiving more attention recently in the context of forecasted changes in the frequency and intensity of extreme events due to climate change (Nobre at al., 2011; Linnekamp et al., 2011; Gu et al., 2011).

There is a significant correlation between human occupation and urban drainage systems. ${ }^{2}$ Urban development promotes changes in land use that increase flood hazards, as changes to stream channels can limit drainage during heavy rainfall (Konrad and Booth, 2002). Megacities such as São Paulo have numerous social and environmental problems associated with patterns of development and transformation of space, which have been aggravated by increases in temperature and intensification of extreme weather events (Nobre et al., 2011; Silva Dias et al., 2013). Projections of climate changes indicate a step up in the frequency and intensity of short lasting extreme events,

\footnotetext{
${ }^{1} \mathrm{We}$ are grateful to Silvio Ichihara and Renato Vieira who provided excellent research support. The authors acknowledge financial support provided by Rede CLIMA and INCT-MC.

${ }^{2}$ The worsening of drainage problems in São Paulo has always been linked to the occupation of the Tiete River plain (Ostrowsky, 1991; Nobre et al., 2011).
} 
and point to an increase in the number of days with heavy rainfall until the end of the century, aggravating further the issue of flooding. ${ }^{3}$

The consequences of floods in urban areas are relevant, ranging from impacts on human health (Huntingford et al., 2007) to effects on housing prices (Harrison et al., 2001), urban transportation infrastructure (Suarez et al., 2005), and other damaging effects such as time lost in work and education, damages to property and psychological stress (Linnekamp et al., 2011); moreover financial costs are also important, through potential effects in the insurance sector and public compensation schemes (Botzen and Van den Bergh, 2008).

Van der Veen and Logtmeijer (2005) discusses [economic] vulnerability to flooding as a function of dependence - the degree to which an activity relates to other economic activities in the rest of the country; redundancy - the ability of an activity (or system) to respond to a disruption by overcoming dependence by deferring, using substitutes or even relocating; and susceptibility - the probability and extent of flooding. Understanding this functional tripod would be essential to identify risk-related economic hotspots associated with a broader concept of damage which should include not only traditional direct damages related to infrastructure, property and business disruption, but also indirect costs measured through input-output linkages.

We operationalize this concept using an alternative methodological approach. The focus of the paper is on one specific dimension of the economic impacts of flooding in an integrated interregional system. We use as our case study all the flooding events that occurred in the city of São Paulo in 2008. As we will analyze every single point of flood in that year, treatment of susceptibility becomes of lesser importance; from the economic standpoint, once the flood took place in a point of the city, we will just need to verify the existence of affected business firms within its territorial extent. The other two elements are also explicitly considered. Dependence is fully captured through spatial linkages associated with the income flows and value chains embedded in the metropolitan input-output system used to calibrate the spatial computable general

\footnotetext{
${ }^{3}$ Even though projections of changes in rainfall and rainfall extremes may still show uncertainties due to climate model difficulties in representing some physical processes related to rainfall formation at higher resolutions (Marengo et al., 2009), significant positive trends are found in the evolution of daily rainfall extremes in the city of São Paulo from 1933 to 2010 historical data (Silva Dias et al., 2013).
} 
equilibrium (SCGE) model, and on hypotheses on interregional factor mobility; redundancy is contemplated on the strength of substitution effects induced by price effects and supply constraints in the SCGE model.

In an economic perspective, three main driving forces come into play: at first, businesses in the influence area of the flood points may have to shut down temporarily, hampering potential GDP/GRP growth through interruptions in their value chains; secondly, damage in the economic infrastructure may generate either a reduction in the capital stocks available for production or, more common in flood events, temporary disruptions of infrastructure services (e.g. electricity disruption, closing of roadways), also negatively impacting the potential GRP/GDP; and thirdly, reconstruction efforts and additional maintenance measures operate in the opposite direction, activating investment-oriented activities (e.g. construction sector), starting more vigorously after the flood periods. This paper aims to evaluate the effects of the first of these three driving forces. We look at the economies of the city of São Paulo and of Brazil in 2008 and estimate what would be the hypothetical economy-wide impact had all flood events not occurred in that year. In doing that, we are able to derive the estimates of the economic costs of the floods related to the value chains disruptions associated with businesses' temporary close downs during the events. By not taking into account the effects of neither disruptions in infrastructure services nor financial flows associated with recovery of the natural disasters, we are able to isolate the economic effects of the flooding and its spatial propagation providing an approximation of the regional consequences from a value chain perspective. Thus, these estimates should be considered as lower bounds of the broader economic costs.

The remaining of the paper is structured as follows. In the next section, we provide more information on the study area, followed by a section in which the methodology is described and estimates of direct effects are shown. The following section presents the economy-wide impacts of the 2008 floods in the city of São Paulo, emphasizing their systemic nature. Final remarks conclude.

\section{The Study Area}


The São Paulo Metropolitan Region (SPMR), the main economic and financial center of Brazil, consists of 39 municipalities in an intense process of conurbation. It is the fourth largest urban agglomeration of the world, and the largest urban agglomeration in the country, with about $10 \%$ of the national population (around 20 million inhabitants), and responsible for $19 \%$ of Brazilian GDP. The city of São Paulo is the core of the metropolitan area and accounts for $5.9 \%$ of the country's population and $12 \%$ of its GDP (Table 1).

Table 1. Basic indicators

\begin{tabular}{|l|c|c|c|c|c|}
\hline & $\begin{array}{c}\text { Area } \\
(\text { OOO } \\
\left.\mathrm{km}^{2}\right)\end{array}$ & $\begin{array}{c}\text { Population } \\
(\text { OO0 000) }\end{array}$ & $\begin{array}{c}\text { GDP } \\
(\text { USD } \\
\text { billion) }\end{array}$ & $\begin{array}{c}\text { Per capita } \\
\text { GDP } \\
\text { (USD) }\end{array}$ & $\begin{array}{c}\text { HDI } \\
2000\end{array}$ \\
\hline $\begin{array}{l}\text { City of São } \\
\text { Paulo }\end{array}$ & 1.5 & 11.3 & 194.6 & 17,221 & 0.841 \\
\hline SPMR & 7.9 & 19.7 & 306.5 & 15,558 & 0.813 \\
\hline Brazil & $8,514.9$ & 190.8 & $1,619.2$ & 8,486 & 0.665 \\
\hline
\end{tabular}

From a stylized perspective, one can notice the existence of an extended central business district (CBD) associated with the spatial configuration of economic activities in the metropolitan area. The CBD concentrates the jobs, while households are located in the surroundings of the center, with population density decay in the boundaries of the territory of the metropolis. As suggested by Figures 1 and 2, the internal organization of the SPMR can be approached by a Muth-Mills-Alonso urban model, having as the CBD the extended center of the city of Sao Paulo. According to the 2010 population census, the city of São Paulo receives daily an inflow of almost 1 million commuters, representing $15.4 \%$ of workers in the city. ${ }^{4}$

Dense urbanization is a significant source of heat. The densest parts of the metropolitan area tend to be the warmest, and temperature decreases as urban density declines (Nobre et al., 2011). The "urban heat-islands" create more summer rain over and downwind of major cities (Shepherd et al., 2002), reinforcing the forecasted trends of increasing

\footnotetext{
${ }^{4}$ Around 170 thousands of São Paulo residents commute daily to other cities, especially in the SPMR.
} 
frequency and intensity of daily rainfall extremes in the city of São Paulo (Silva Dias, 2013).

Figure 1. Where people live - Population density in the SPMR

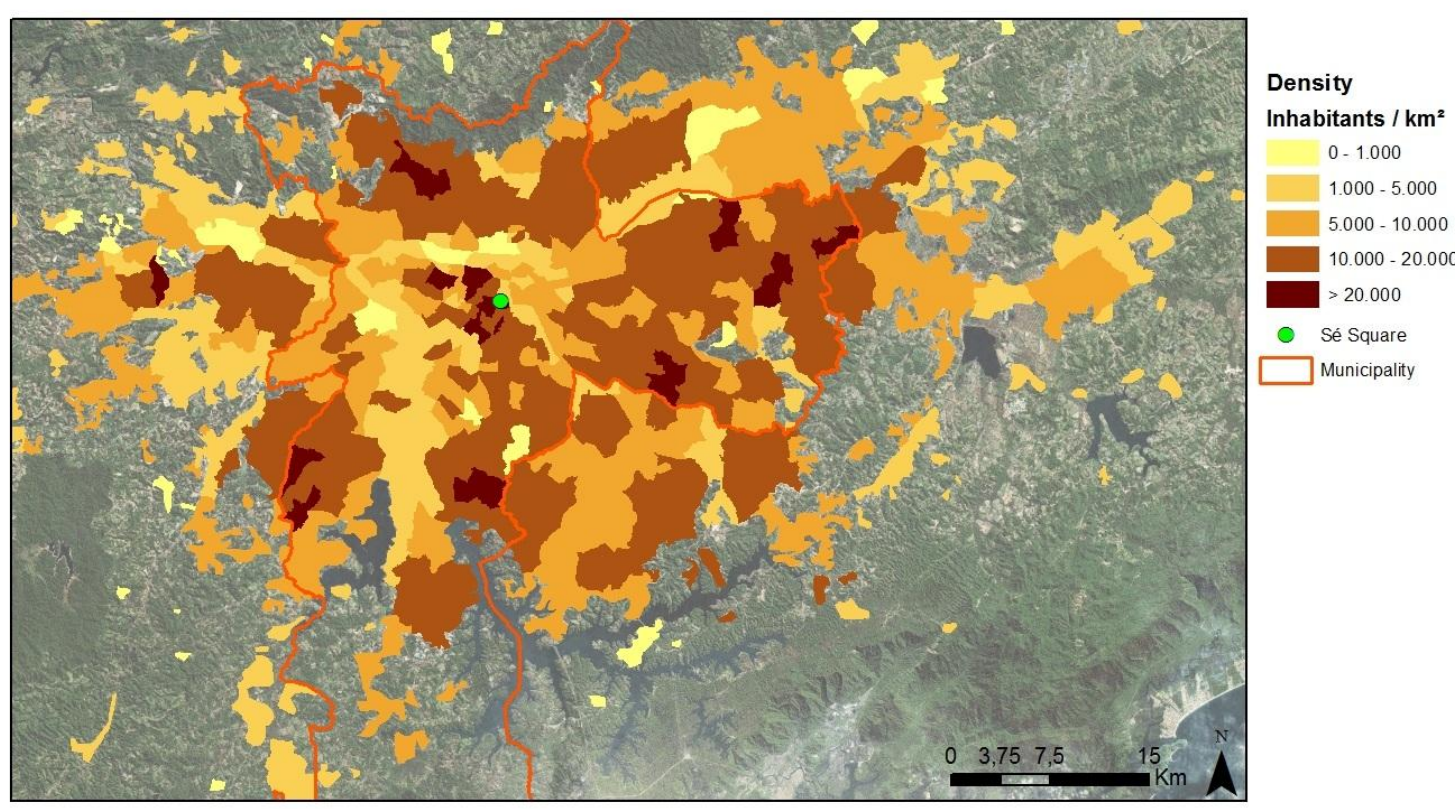

Source: Companhia do Metropolitano de São Paulo

Figure 2. Where people work - Employment density in the SPMR

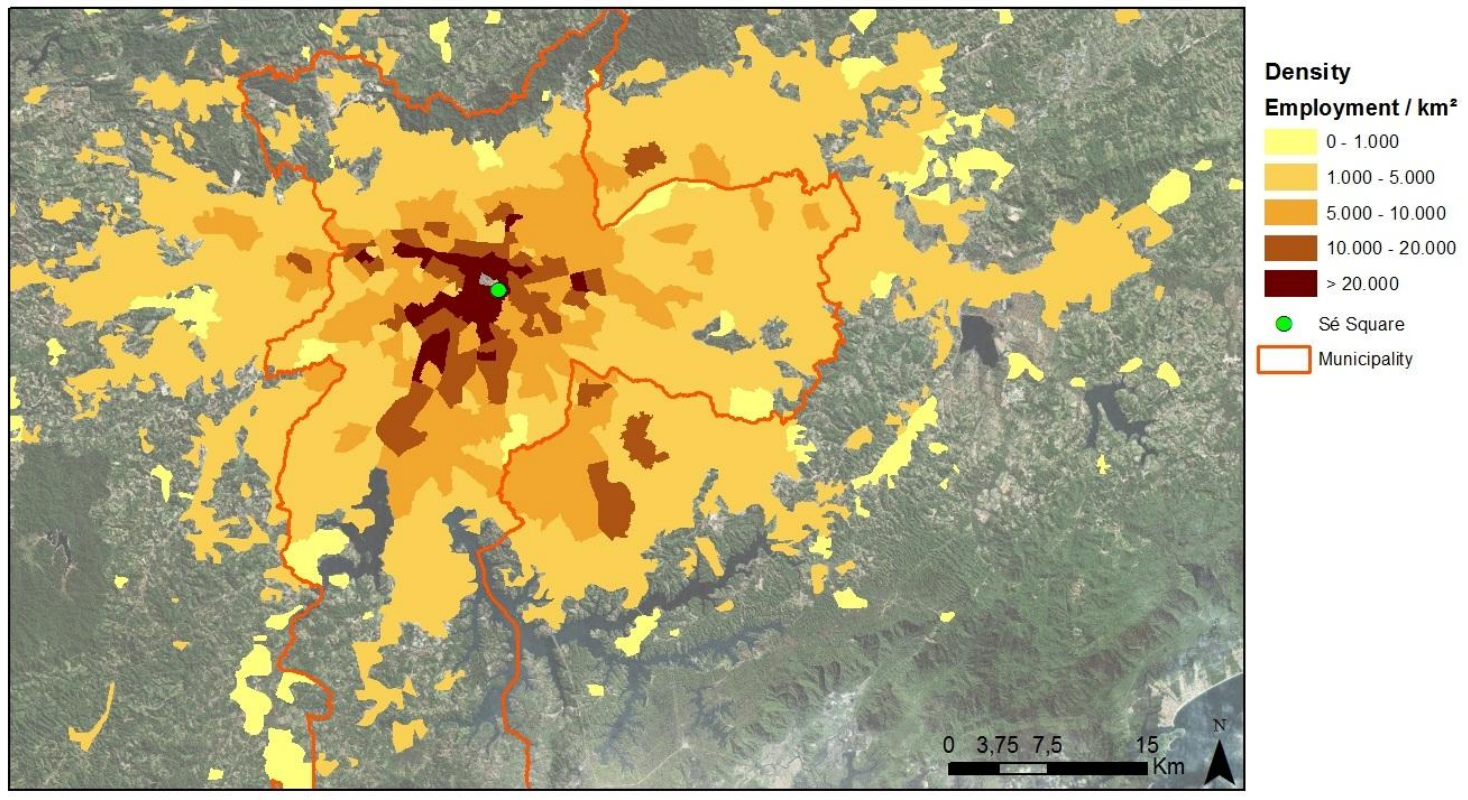

Source: Companhia do Metropolitano de São Paulo 
The rapid process of urban expansion around the CBD (Figure 3) was not followed by the implementation of adequate infrastructure, causing important urban problems. Due to the lack of urban planning and the illegal occupation of the environmental protection areas (around watercourses and on slopes), the percentage of impervious areas in the Upper Tietê River Basin, the main watercourse in the city, has increased significantly. As a result, flood frequency in the basin has also increased (Barros et al., 2005).

Figure 3. Urban sprawl of the SPMR, 1881-1995

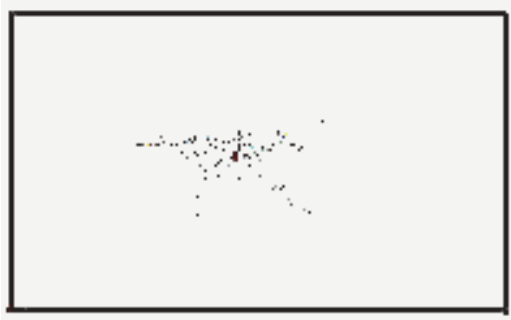

1881

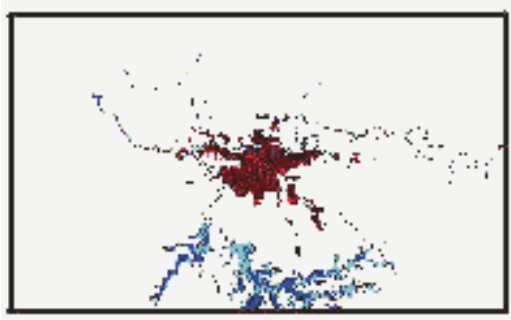

1930

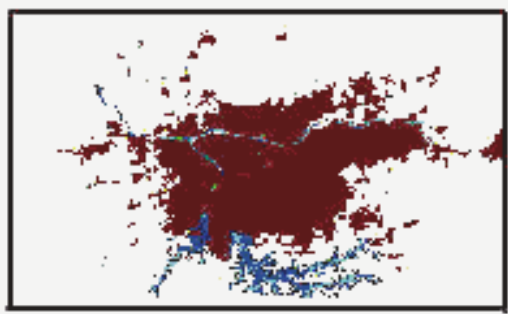

1972

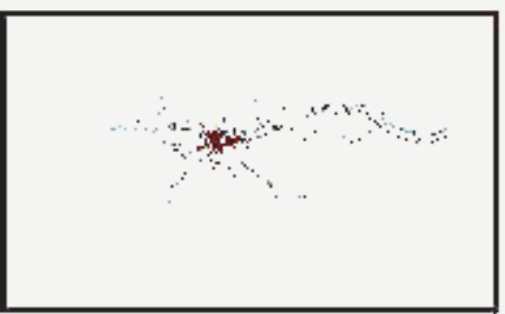

1905

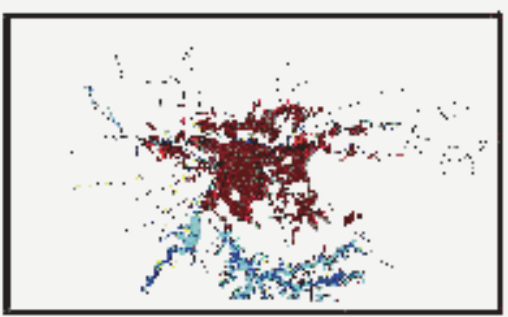

1952

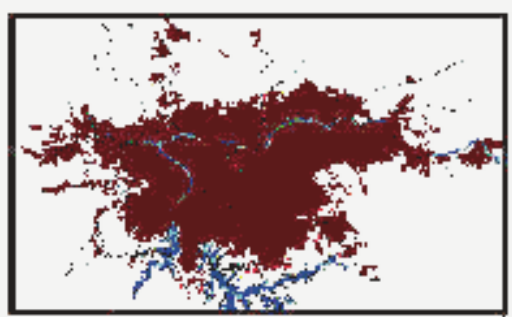

1983

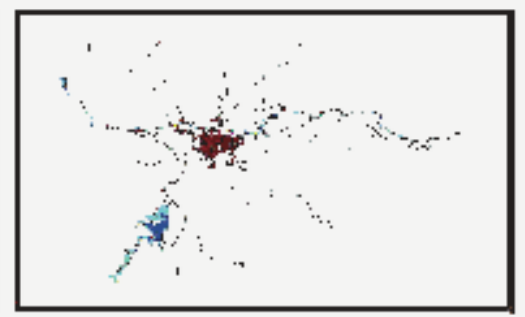

1914

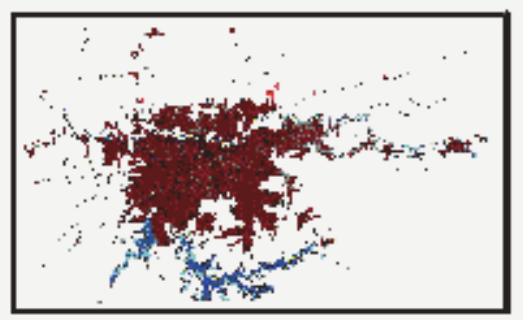

1962

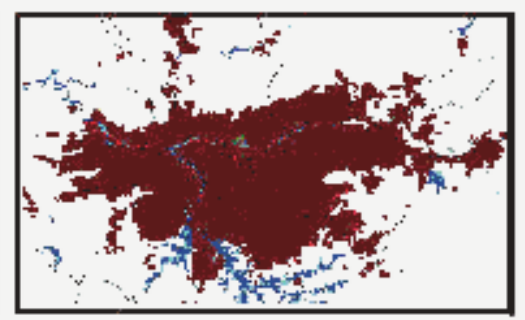

1995

Source: CESAD-FAU/USP - http://www.cesadweb.fau.usp.br/

Among the main issues currently faced by the city are those related to climate change. The intense rainfall in the summer causes floods in several points of the town. Besides the loss and inconvenience suffered by people directly affected, these floods produce wider effects that surpass the limits of the city, reflecting on economic sectors of the state and the country. The impacts of floods affect households, industrial and 
commercial activities, public and private services, and the urban transportation system. Given the increasing concentration of people and economic activities in the area in the past decades, impacts and economic losses due to natural catastrophes have increased substantially.

Since the early 1970s, the SPMR has undergone major structural changes, transformed from dominance by traditional manufacturing to more sophisticated services. ${ }^{5}$ The hollowing-out process of the metropolitan area associated with the geographical deconcentration of the manufacturing sector has imposed a new structure of interregional dependence in which SPMR plays a specific role. On one hand, a typical establishment is now less dependent both on sources of inputs and on markets within the metropolitan area. On the other hand, fragmentation is now a characteristic of production with longer value chains based on the organization of production to exploit economies of scale in individual plants in specialized component production - and shipping to other plants elsewhere to add further components (Hewings, 2012). Table 2 reveals the structure of interregional and international trade flows with special attention to the city of São Paulo and the remaining metropolitan area. The São Paulo city is directly involved in $14.1 \%$ of all trade flows of the country, including both domestic and international trade partners. Intra-city trade corresponds to $36.6 \%$ of total trade flows of the city, while the remaining $63.4 \%$ are distributed between interregional trade $(17.0 \%$ within the metropolitan area and $38.6 \%$ with other Brazilian regions) and international trade (7.8\%). This important share of domestic trade outside the metropolitan area reflects the aforementioned process of hollowing-out and spatial fragmentation that started during the 1970s in Brazil, when the manufacturing sector relocate to other regions outside the SPMR (Diniz, 1994). A closer look at the structure of trade flows by sectoral products reveals the stronger dependence of São Paulo city on primary and manufactured products from outside the metropolitan boundaries and a relative self-sufficiency in services.

It is in this context that the assessment of the impacts of floods in the city of São Paulo is to be undertaken. Even though there is a strong perception that, apart from the damage and inconvenience suffered by those directly affected, flooding in the Upper

\footnotetext{
${ }^{5}$ The share of SPMR in the national manufacturing output dropped from over $40 \%$ in the 1970 s to less than $20 \%$ in the recent years.
} 
Tietê Basin in São Paulo could produce wider effects stretching beyond regional boundaries, with devastating effects on the state and national economies (Nobre at al., 2011), this is, to our knowledge, the first attempt to address this issue in an integrated modeling approach.

Table 2. Structure of trade flows in Brazil, 2008 (in \% of total)

\begin{tabular}{|c|c|c|c|c|c|c|}
\hline & \multicolumn{6}{|l|}{ Primary ( $8.5 \%$ of total flows) } \\
\hline & & \multicolumn{5}{|c|}{ Destination } \\
\hline \multirow{6}{*}{ 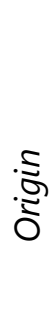 } & & $S P C$ & SPMR & $R S P$ & $R B$ & ROW \\
\hline & São Paulo City (SPC) & 0,00 & 0,01 & 0,00 & 0,00 & 0,00 \\
\hline & Rest of SPMR (SPMR) & 0,01 & 0,02 & 0,01 & 0,00 & 0,00 \\
\hline & Rest of São Paulo State (RSP) & 0,54 & 0,35 & 3,60 & 1,88 & 0,26 \\
\hline & Rest of Brazil (RB) & 1,93 & 1,58 & 13,25 & 47,67 & 16,88 \\
\hline & Rest of the world (ROW) & 0,28 & 0,35 & 3,46 & 7,93 & 0,00 \\
\hline
\end{tabular}

\section{Manufacturing ( $36.6 \%$ of total flows)}

\begin{tabular}{|c|c|c|c|c|c|}
\hline São Paulo City (SPC) & 1,81 & 1,03 & 0,82 & 1,46 & 0,55 \\
\hline Rest of SPMR (SPMR) & 1,77 & 2,14 & 1,00 & 1,65 & 0,89 \\
\hline Rest of São Paulo State (RSP) & 2,31 & 1,52 & 8,10 & 7,06 & 3,32 \\
\hline Rest of Brazil (RB) & 1,00 & 0,64 & 3,14 & 39,87 & 6,50 \\
\hline Rest of the world (ROW) & 1,28 & 1,06 & 2,36 & 8,74 & 0,00 \\
\hline
\end{tabular}

\section{Services (54.9\% of total flows)}

\begin{tabular}{l|ccccc}
\multicolumn{7}{c}{} & SPC & SPMR & RSP & RB & ROW \\
\cline { 2 - 6 } \multicolumn{1}{l}{} & 8,22 & 1,82 & 2,01 & 3,32 & 0,46 \\
São Paulo City (SPC) & 0,68 & 3,02 & 0,49 & 0,81 & 0,18 \\
Rest of SPMR (SPMR) & 0,28 & 0,22 & 9,04 & 1,89 & 0,40 \\
Rest of São Paulo State (RSP) & 0,28 & 1,34 & 61,13 & 1,98 \\
Rest of Brazil (RB) & 0,20 & 0,18 & 1,34 & 0,00
\end{tabular}

Total ( $100.0 \%$ of total flows)

\begin{tabular}{l|ccccc}
\multicolumn{1}{c}{} & \multicolumn{5}{c}{ Destination } \\
\cline { 2 - 6 } & SPC & SPMR & RSP & RB & ROW \\
\cline { 2 - 6 } São Paulo City (SPC) & 5,17 & 1,38 & 1,41 & 2,36 & 0,45 \\
Rest of SPMR (SPMR) & 1,02 & 2,44 & 0,64 & 1,05 & 0,42 \\
亏5 Rest of São Paulo State (RSP) & 1,04 & 0,71 & 8,23 & 3,78 & 1,46 \\
Rest of Brazil (RB) & 0,64 & 0,46 & 3,01 & 52,20 & 4,90 \\
Rest of the world (ROW) & 0,64 & 0,49 & 1,34 & 4,75 & 0,00 \\
\hline
\end{tabular}

Source: SCGE database 


\section{The Integrated Modeling Framework}

The purpose of this study is to evaluate the wider economic impacts of floods in the city of Sao Paulo through a bottom-up modeling approach. In this context, the economic consequences of localized floods are assessed from the municipal to the national level. As highlighted by Rose (2004), the quantification of economic losses is necessary to gauge individual and community vulnerability, to evaluate the worthiness of mitigation, to determine the appropriate level of disaster assistance, to improve recovery decisions, and to inform insurers of their potential liability.

Natural disasters can cause physical destruction of installed capacity. However, the city of Sao Paulo has been adapting to the type of flooding that it experiences. Despite the inconvenience caused, such as the interruption of the flow of people and goods due to the lack of urban drainage, the loss of machinery and equipment are negligible in such events. In our approach, the economic losses of the main economic and financial center of the country are directly related to the shutdown of production in the affected sites. While the direct losses are assessed through the disruption of economic activities, indirect losses can be calculated by considering associated interruptions in the value chains. Such estimation of indirect losses demands an economic model capable of capturing the flow of goods between economic agents, which poses another challenge, given the uniqueness of each disaster (Okuyama, 2007).

\section{Estimating the direct impact of the 2008 flooding events in the city of São Paulo}

Using detailed GIS information on flooding points and on labor profiles of firms, and assuming that production is a continuous on weekdays, foregone losses can be indirectly approached by a measure of foregone wages paid during the interruption of production in businesses affected by flooding events.

The information on flooding in São Paulo is provided by the Emergency Management Center (EMC) of São Paulo local government. The EMC database informs, for each flooding point, its exact location, date of occurrence, starting time and duration, as well as a qualitative assessment of the intensity of the event. With the geo-referencing of the flooding database for 2008, and integrating these data with firms' location through GIS 
techniques, it is possible to locate all businesses impacted by floods in a pre-defined impact radius. ${ }^{6}$

The information on payments to workers in the affected firms is essential to capture the direct losses caused by flooding. These data are obtained from a GIS database on labor firms, known in Brazil as RAIS (Annual Report of Social Information). ${ }^{7}$ The RAIS database informs, for each single firm, its address, total wages paid to workers, and the SIC code of its main activity. This statistical survey covers $97 \%$ of the formal labor market, which represents $57 \%$ of the total employment in the country ${ }^{8}$, providing a measure of the representativeness of the sample. A simple reweighting procedure is used based on the information on sectoral labor payments in the CGE database, so that the aggregated micro data on the workers' wage bill in a given sector in the city of São Paulo would be consistent with the macro data.

The combination of these two databases allows us to identify those businesses potentially affected by a flood event (Figure 4). To calibrate the area of influence of a flood point in our simulations, 25 interviews were undertaken with firms locate in the vicinity of two specific flood points in our database. ${ }^{9}$ The main conclusions of the field research were that (i) up to $100 \mathrm{~m}$ from the flood point (approximately one block), firms are definitely affected - depending on the time of the event, workers either do not arrive at work or leave the job place earlier; (ii) firms further away (e.g. 200m) are only affected in the most severe events; and (iii) in the rare occasions when the water invades the establishment, precautionary adaptive measures are promptly undertaken for the next event. Thus, the most likely scenario would be to define an impact radius of $100 \mathrm{~m}$ and not to consider damage to capital stocks. Moreover, to calibrate our simulations, we have an additional ad hoc assumption that the extension of the foregone output will depend on the time of the day the flood event takes place: for events that take place before noon (after 6am), it will be assumed that the whole daily output is "lost", while only half of it will be considered to be "lost" in cases the flood occurs in the afternoon, during working hours. Thus, once the companies directly affected by the flood events

\footnotetext{
${ }^{6}$ We excluded from the analysis flood events that took place in the idle of the night or on weekends and holidays. Since the vast majority of flood-related problems last fewer than several hours, as businesses are probably closed anyway and there is no disruption for the most part (Rose and Guha, 2004).

${ }^{7}$ Ministry of Labor and Employment.

${ }^{8}$ IBGE (Brazilian Institute of Geography and Statistics).

${ }^{9}$ Lapa and CEAGESP areas.
} 
are identified under our working hypotheses, one can estimate foregone losses in the periods of interrupted production. Such information is used to prepare the shock vector that feeds the SCGE model so that one can evaluate the total economic impacts of floods in São Paulo.

Estimated direct foregone labor income due to floods in 2008 in the city of São Paulo is presented in Table 3. Direct impact is heavily concentrated in tertiary activities (around 90\%), especially services, commerce and transportation. In the more plausible scenario, i.e. $100 \mathrm{~m}$, almost 20,000 firms would have been directed affected by flood events in 2008, with a labor income loss of over BRL 17 million. In terms of foregone output, this is close to BRL 80 million (BRL 43.5 million in terms of value added).

Figure 4. Example of GIS-based influence area of flood points, for different scenarios $(50 \mathrm{~m}, 100 \mathrm{~m}, 150 \mathrm{~m}, 200 \mathrm{~m})$

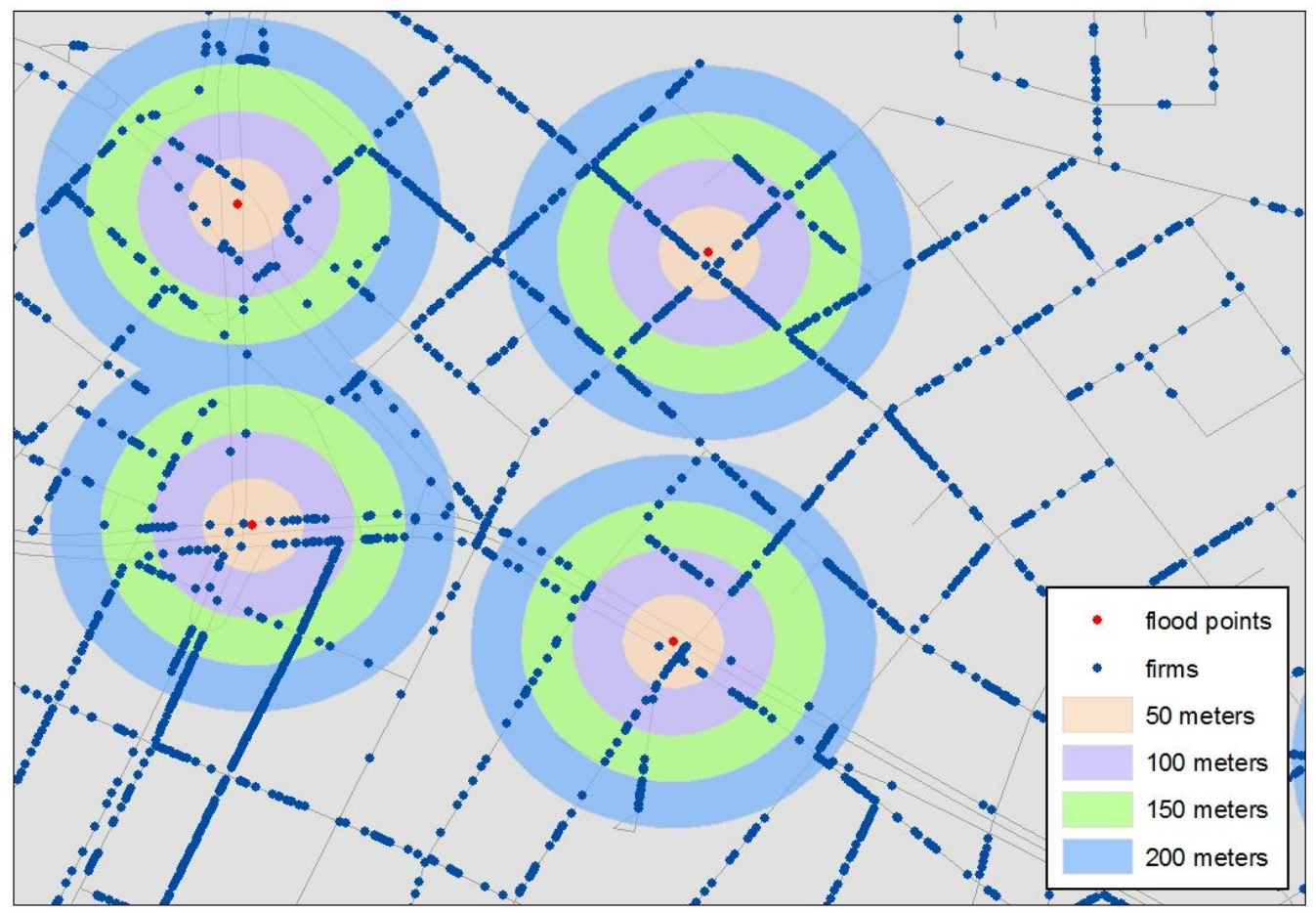


Table 3. Estimated foregone (reweighted) labor income (in BRL thousand)

\begin{tabular}{lrrrr}
\hline & \multicolumn{4}{c}{ Impact radius } \\
& \multicolumn{1}{c}{$50 \mathrm{~m}$} & $100 \mathrm{~m}$ & $150 \mathrm{~m}$ & \multicolumn{2}{c}{$200 \mathrm{~m}$} \\
\cline { 2 - 5 } Primary & 7.08 & 9.92 & 22.39 & 33.13 \\
Manufacturing & 454.01 & $2,014.94$ & $3,131.36$ & $5,557.37$ \\
Utilities & 673.48 & $1,444.40$ & $1,795.81$ & $2,146.47$ \\
Construction & 185.72 & 589.96 & $1,034.77$ & $1,778.95$ \\
Commerce & $1,057.58$ & $2,046.03$ & $3,702.56$ & $6,024.32$ \\
Transportation & 663.62 & 948.01 & $1,483.51$ & $1,933.59$ \\
Services & $3,132.72$ & $9,034.60$ & $16,445.59$ & $31,519.12$ \\
Public administration & 300.43 & $1,354.86$ & $15,233.56$ & $16,317.47$ \\
TOTAL & $6,474.63$ & $17,442.72$ & $42,849.55$ & $65,310.42$ \\
\# of affected firms & 8,577 & 19,784 & 35,896 & 57,938 \\
\hline
\end{tabular}

\section{Estimating the impacts at the regional and national levels}

In order to estimate the total impacts caused by floods in São Paulo we use a spatial computable general equilibrium model (SCGE). It is a model based on simultaneous optimization of the behavior of individual consumers and firms, subject to resource constraints. When extended into a multi-regional framework, the model is able to provide the spatial distribution of impacts.

The specification of the SCGE model uses as its departure point the B-MARIA model, developed by Haddad (1999). The B-MARIA model - and its extensions - has been widely used for assessing regional impacts of economic policies in Brazil. Since the publication of the reference text, various studies have been undertaken using, as their basic analytical tool, variations of the original model. The theoretical structure of the BMARIA model is well documented. Results are based on a bottom-up approach - i.e. national results are obtained from the aggregation of regional results. The model identifies different production/investment sectors in each region producing different commodities, one representative household in each region, regional governments and one Federal government, and a single foreign area that trades with each domestic region, through a network of ports of exit and ports of entry. Three local primary factors 
are used in the production process, according to regional endowments (land, capital and labor).

The B-MARIA framework includes explicitly some important elements from an interregional system, needed to better understand macro spatial phenomena, namely: interregional flows of goods and services, transportation costs based on origindestination pairs, interregional movement of primary factors, regionalization of the transactions of the public sector, and regional labor markets segmentation. We have also introduced the possibility of (external) non-constant returns in the production process, following Haddad and Hewings (2005). This extension is essential to adequately represent one of the functioning mechanisms of a spatial economy. The model used here is structurally calibrated for 2008 , the same year for which data on floods are available. The calibration of the SCGE model is based on a fully specified interregional inputoutput system considering 41 regions, 56 sectors and 110 products. ${ }^{10}$ It is a database at the municipal level for the year 2008 which focuses on the SPMR, that is, it covers the 39 municipalities that compose the metropolitan area, the rest of the state of São Paulo and the rest of Brazil. Furthermore, it maps the inter-industrial relations by place of production; the payments to labor factor by place of residence; and the consumption structure by place of consumption (Figure 5). ${ }^{11}$

\footnotetext{
${ }^{10}$ Due to computational constraints, we have used an aggregated version with 8 sectors and 8 products.

11 These different spatial dimensions follow the tradition found in metropolitan input-output models (Hewings et al., 2001; Jun, 2004).
} 
Figure 5. Input-output relations embedded in the spatial CGE model

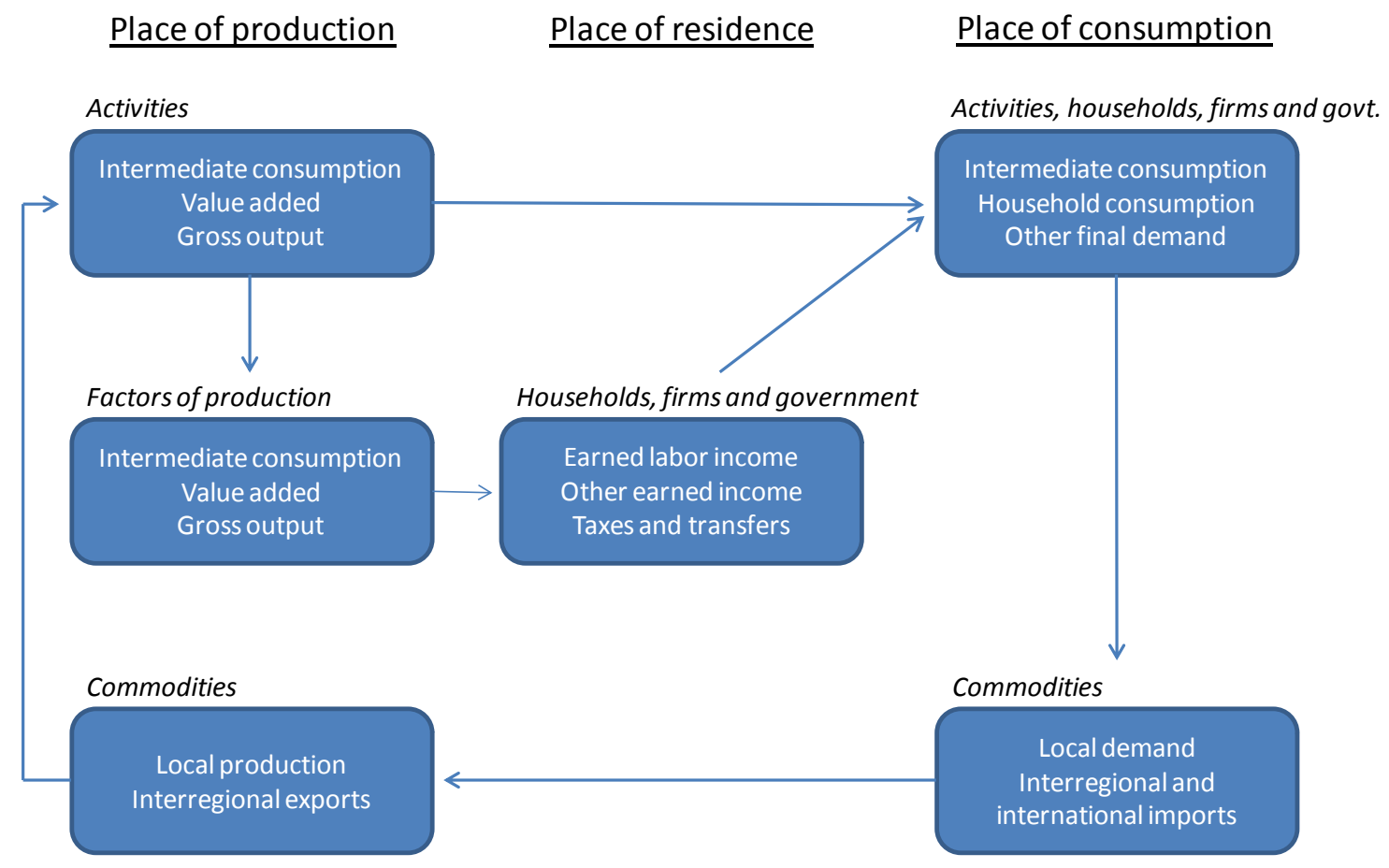

\section{The Economy-wide Impacts of the 2008 Floods in São Paulo City}

What if floods had not occurred in the city of São Paulo in 2008? What would be the difference in terms of value added (GRP/GDP) for the city and for other regions of the country? Results of the SCGE simulations for the four scenarios were computed via a 12-4 Euler procedure with extrapolation, under a short-run closure (exogenous capital stocks). In what follows, we focus our analysis on the $100 \mathrm{~m}$-scenario. Results for the remaining simulations are qualitative similar.

Table 4 shows the results for the macroeconomic effects of the 2008 floods generated by the SCGE simulation. It can be seen that it is expected floods to lower the São Paulo city GRP by $0.0263 \%$ and the national GDP by $0.0071 \%$. Despite the localized occurrence of floods within the city limits, they reduce output growth beyond its territory. They also contribute to a decline in welfare of city residents (lower real 
household consumption), a reduction in tax revenue ${ }^{12}$, and a decrease in the city's domestic and international competitiveness, as verified by the worsening of the interregional and international balances of trade. The national effects go in the same direction, with lower welfare and government expenditures, and a decrease in the country's competitiveness in international markets.

From a spatial perspective, Figure 6 presents the impacts on municipalities in the SPMR. Noteworthy is that the economic effects are not only local - they spread across the space through production and income linkages. We see that the effects of the floods are estimated to vary considerably across municipalities in the SPMR. As expected, the largest negative effects of the floods - besides that on São Paulo City - are projected to occur in municipalities with stronger production and income coefficients linked to the capital city.

In money values, the total value added impact on the Brazilian economy is estimated to be BRL 218.19 million (100m-scenario), for a direct damage of BRL million 43.54, so that the associated total impact-damage ratio is 5.0. Considering only the intra-city impact, the impact-damage ration is equivalent to 2.2 (Table 5). Given the existing spatial fragmentation observed in Brazil, and the structure of spatial dependence observed in the data (Table 2), the hierarchy of impacts shows the rest of Brazil as the second most affected region, with potential GRP losses similar in magnitude to those projected for São Paulo City. The rest of the State of São Paulo, benefitted by the recent process of hollowing-out of the SPMR, presents potential GRP losses greater than the totality of the other municipalities in the SPMR. Roughly, the GDP impact in all scenarios is spatially distributed as follows: São Paulo City and the rest of the country with similar shares in total losses of around 44\%; the rest of São Paulo State with 9\%, and the remaining $4 \%$ accruing to the rest of SPMR.

\footnotetext{
12 Our assumption regarding adjustment in the real government expenditure considers constant real budget deficits for both regional and federal governments.
} 
Figure 6. Potential GRP losses in the RMSP municipalities, 100m scenario

In \% of 2008 GRP

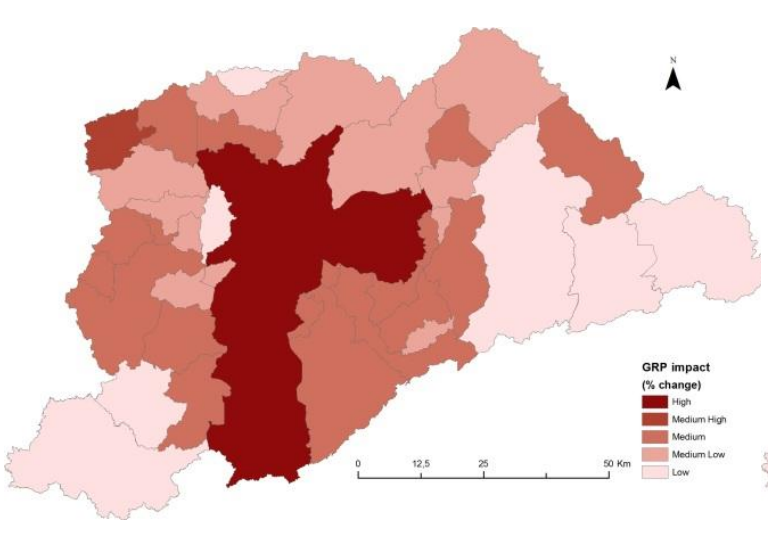

In BRL 2008

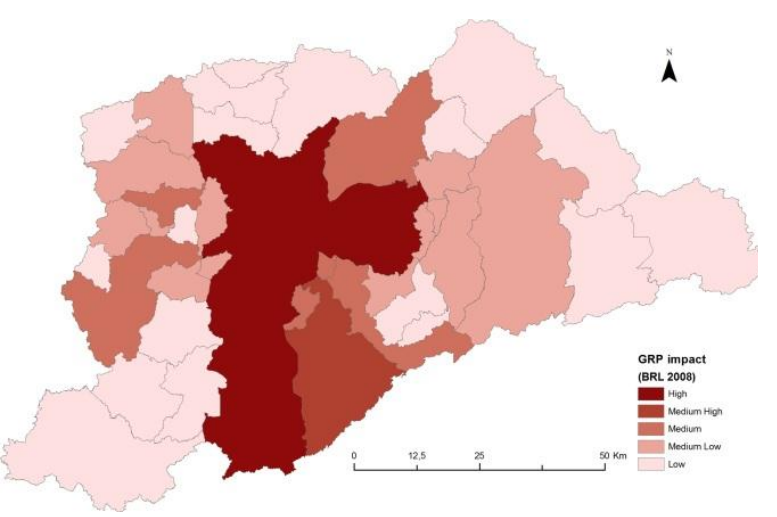

Table 4. Macroeconomic impacts of floods, 2008

(in percentage change)

\section{City of São Paulo}

Real GRP

Real household consumption

Real government consumption - Regional

Real government consumption - Federal

Real investment

Interregional export volume

International export volume

International import volume
Interregioanal import volume

Impact radius

\begin{tabular}{cccc}
$50 m$ & $100 m$ & $150 m$ & $200 m$ \\
\hline & & & \\
-0.0112 & -0.0263 & -0.0418 & -0.0692 \\
-0.0028 & -0.0059 & -0.0008 & -0.0067 \\
-0.0033 & -0.0094 & -0.0304 & -0.0446 \\
-0.0024 & -0.0062 & -0.0120 & -0.0204 \\
- & - & - & - \\
-0.0090 & -0.0223 & -0.0379 & -0.0628 \\
0.0005 & 0.0006 & 0.0023 & 0.0008 \\
-0.0264 & -0.0578 & -0.0932 & -0.1493 \\
0.0051 & 0.0109 & 0.0177 & 0.0257
\end{tabular}

\section{Brazil}

Real GDP

Real household consumption

Real investment

Real government consumption - Regional

Real government consumption - Federal

International export volume

International import volume

$\begin{array}{cccc}-0.0030 & -0.0071 & -0.0114 & -0.0183 \\ -0.0013 & -0.0033 & -0.0054 & -0.0097 \\ - & - & - & - \\ -0.0022 & -0.0060 & -0.0141 & -0.0229 \\ -0.0024 & -0.0062 & -0.0120 & -0.0204 \\ -0.0087 & -0.0188 & -0.0271 & -0.0405 \\ 0.0032 & 0.0067 & 0.0088 & 0.0123\end{array}$


Table 5. Direct and total GRP/GDP impact (in BRL million)

\begin{tabular}{lcccc}
\hline & \multicolumn{4}{c}{ Impact radius } \\
& \multicolumn{5}{c}{$50 \mathrm{~m}$} & $100 \mathrm{~m}$ & $150 \mathrm{~m}$ & $200 \mathrm{~m}$ \\
\cline { 2 - 5 } Direct loss & & & & \\
São Paulo City (SPC) & 16.63 & 43.54 & 88.30 & 143.53 \\
Total loss & & & & \\
São Paulo City (SPC) & 40.08 & 94.38 & 150.34 & 248.55 \\
Rest of SPMR (SPMR) & 3.35 & 9.05 & 12.72 & 19.66 \\
Rest of São Paulo State (RSP) & 9.14 & 21.04 & 32.49 & 49.86 \\
Rest of Brazil (RB) & 39.95 & 93.72 & 154.91 & 246.10 \\
Brazil & 92.52 & 218.19 & 350.46 & 564.17 \\
& & & & \\
Intra-city total impact-damage ratio & $\mathbf{2 . 4}$ & $\mathbf{2 . 2}$ & $\mathbf{1 . 7}$ & $\mathbf{1 . 7}$ \\
Economy-wide total impact-damage ratio & $\mathbf{5 . 6}$ & $\mathbf{5 . 0}$ & $\mathbf{4 . 0}$ & $\mathbf{3 . 9}$ \\
\hline
\end{tabular}

\section{Final Remarks}

Throughout most of the $20^{\text {th }}$ century, the number of days when rainfall exceeded 80 $\mathrm{mm}$ /day in São Paulo was very small (one per decade since the 1930s). After the early 1970s, however, the number of cases increased, reaching nine cases in the first decade of this century (Silva Dias et al., 2013). Using a SCGE model, we have ascribed output shocks based on GIS simulations in which locations of flood points and firms were combined, in projecting the economic impacts of flood events that took place in the city of São Paulo in 2008. It was estimated that floods contributed to reduce city growth and residents welfare, as well as to hamper local competitiveness in both domestic and international markets. Not only was the city economy affected, but also other regional economies in Brazil.

The key message is that one needs to consider interactions both inside and outside an urban system to assess the consequences of apparently local phenomena. Measures relating to the planning and control of land use should be executed in parallel with engineering projects to improve the urban drainage system and prevent the emergence of new risk areas. However, the recognition that the economic effects of flooding are not only local poses an additional governance problem in the context of Brazilian federalism. As policy decisions (and budget controls) are made either at the 
municipality, state or federal level, coordination problems will be faced. As Biesbroek et al. (2009) pointed out, there is no unequivocal solution to the challenge of climate change, which will require a combination of long-term efforts and short-term actions taken at all governmental levels. In the context of the problems of floods in São Paulo, a further challenge emerges as, in addition to the traditional administrative structures that spatial planners are accustomed to - which favor the treatment of socioeconomic issues - additional spatial layers come into scene (e.g. river basins, climate) bringing other dimensions to be integrated in the search for a solution.

\section{References}

BARROS, M. T. L., BRANDÃO, J. L. B., SILVA, O. F., ONO, S.. The impact of urban sprawl on flood risk áreas. In: MOGLEN, Glenn E.. Managing watersheds for human and natural impacts: engineering, ecological, and economic challenges. Williamsburg, VA: American Society of Civil engineers, 2005.

BIESBROEK, G. Robert, SWART, Rob j., VAN DER KNAAP, Wim G. M.. The mitigation-adaptation dichotomy and the role of spatial planning. Habitat International, v. 33, p. 230-237, 2009.

BOTZEN, W. J. W., VAN DEN BERGH, J. C. J. M.. Insurance Against Climate Change and Flooding in the Netherlands: Present, Future, and Comparison with Other Countries. Risk Analysis, v. 28, p. 413-426, 2008.

DINIZ, C. C.. Polygonized development in Brazil: neither decentralization no continued polarization. International Journal of Urban and Regional Research, v. 18, n.2, p. 293314, 1994.

GU, Chaolin, HU, Lingqian, ZHANG, Xiaoming, WANG, Xiaodan, GUO, Jing.

Climate change and urbanization in the Yangtze River Delta. Habitat International, v. 35, p. 544-552, 2011.

HADDAD, Eduardo A.. Regional inequality and structural changes: lessons from the Brazilian economy. Aldershot: Ashgate, 1999.

HADDAD, Eduardo A., HEWINGS, Geoffrey J. D.. Market imperfections in a spatial economy: some experimental results. The Quarterly Review of Economics and Finance, v. 45, n. 2, p. 476-496, 2005. 
HARRISON, David M., SMERSH, Greg T., SCHWARTZ Jr., Arthur L..

Environmental determinants of housing prices: the impact of flood zone status. The Journal of Real Estate Research, v. 21, n. 1/2, p. 3-20, 2001.

HEWINGS, Geoffrey J. D.. Urban dynamics: some critical modeling issues. Paper presented at the conference on "Future challenges of the new urban world: what model of development for the Moroccan city?", Rabat: IRES, October 1-2, 2012.

HEWINGS, Geoffrey J. D., OKUYAMA, Yasuhide, SONIS, Michael. Economic interdependence within the Chicago Metropolitan region: a Miyazawa analysis. Journal of Regional Science, v. 41, n. 2, p. 195-217.

HUNTINGFORD, C., HEMMING, D., GASH, J. H. C., GEDNEY, N., NUTTALL, P.

A.. Impact of climate change on health: what is required of climate modellers?

Transactions of the Royal Society of Tropical Medicine and Hygiene, v. 101, p. 97-103, 2007.

JUN, Myung-Jin. A metropolitan input-output model: multisectoral and multispatial relations of production, income formation, and consumption. Annals of Regional Science, v. 38, p. 131-147, 2004.

KONRAD, C. P., BOOTH, D. B.. Hydrologic trends associated with urban development for selected streams in the Puget Sound Basin, Western Washington. U.S. Geological Survey, Water-Resources Investigations Report 02-4040, accessed on February 15, 2013, http://pubs.usgs.gov/wri/wri024040/.

LINNEKAMP, F., KOEDAM, A., BAUD, I. S. A.. Household vulnerability to climate change: Examining perceptions of households of flood risks in Georgetown and Paramaribo. Habitat International, v. 35, p. 447-456, 2011.

MARENGO, J. A., JONES, R., ALVES, L. M., VALVERDE, M. C.. Future change of temperature and precipitation extremes in South America as derived from the PRECIS regional climate modeling system. International Journal of Climatology, v. 29, p. 22412255, 2009.

NOBRE, C. et al.. Vulnerability of Brazilian megacities to climate change: The São Paulo Metropolitan Region (RMSP). In: MOTTA, Ronaldo S., HARGRAVE, Jorge, LUEDEMANN, Gustavo, GUTIERREZ, Maria B. S.. Climate change in Brazil: economic, social and regulatory aspects. Brasília: IPEA, 2011.

OKUYAMA, Yasuhide. Economic modeling for disaster impact analysis: past, present, and future. Economic Systems Research, v. 19, n. 2, p. 115-124, 2007. 
OSTROWSKY, Maria de S. B.. Urbanização e controle de enchentes: o caso de São Paulo (Urbanization and flood control: the case of São Paulo). Master Thesis, Escola Politécnica, Universidade de São Paulo, 1991.

ROSE, Adam. Economic principles, issues, and research priorities in hazard loss estimation. In: OKUYAMA, Yasuhide; CHANG, Stephanie E.. Modeling spatial and economic impacts of disasters. New York: Springer, 2004.

ROSE, Adam, GUHA, G. S.. Computable general equilibrium modeling of electric utility lifeline losses from earthquakes. In: OKUYAMA, Yasuhide; CHANG, Stephanie E.. Modeling spatial and economic impacts of disasters. New York: Springer, 2004. SHEPHERD, J. Marshall, PIERCE, Harold, NEGRI, Andrew J.. Rainfall modification by major urban areas: observations from spaceborne rain radar on the TRMM satellite. Journal of Applied Meteorology, v. 41, p. 689-701, 2002. SILVA DIAS, Maria A. F., DIAS, Juliana, Carvalho, Leila M. V., Freitas, Edmilson D., Silva Dias, Pedro L.. Changes in extreme daily rainfall for São Paulo, Brazil. Climatic Change, v. 116, p. 705-722, 2013.

SUAREZ, Pablo, ANDERSON, William, MAHAL, Vijay, Lakshmanan, T. R.. Impacts of flooding and climate change on urban transportation: a systemwide performance assessment of the Boston Metro Area. Transportation Research Part D, v. 10, p. 231244, 2005.

VAN DER VEEN, Anne and LOGTMEIJER, Christiaan. Economic hotspots: visualizing vulnerability to flooding. Natural Hazards, v. 36, p. 65-80, 2005. 